\title{
$>$ Discutir pensamentos, palavras e imagens
}

\author{
$>$ To discuss thoughts, words and images
}

\begin{abstract}
por Alexandre Santos
É graduado em História pela UFRGS, mestre e doutor em Artes Visuais, pelo PPGAV/UFRGS, com ênfase em História, Teoria e Crítica de Arte. É Professor Associado no Departamento de Artes Visuais (DAV) do Instituto de Artes da UFRGS desde 2007, atuando na graduação (Bacharelado em História da Arte, Bacharelado em Artes Visuais, Licenciatura em Artes Visuais) e na pós-graduação como Docente Permanente do Programa de Pós-Graduação em Artes Visuais do IA-UFRGS. É líder do Grupo de Pesquisa do $\mathrm{CNPq}$ Deslocamentos da fotografia na arte. Desenvolve projeto de pesquisa envolvendo a presença da fotografia na modernidade e contemporaneidade artísticas, com especial interesse pela questão das micronarrativas e da autorreferencialidade.

E-mail:alesan@terra.com.br. ORCID: 0000-0002-0413-2268.
\end{abstract}

É com grande entusiasmo que lançamos a primeira edição da Revista PHILIA | Filosofia, Literatura \& Arte em sua nova linha editorial, que congrega os programas de pós-graduação em Filosofia, Letras e Artes Visuais da Universidade Federal do Rio Grande do Sul. Diante de um contexto no qual a arte a partir dos anos 1960 trouxe entre seus desafios a discussão sobre a falência da pureza dos meios - já presente em algumas tendências das vanguardas do início do século XX -, percebe-se que há uma aproximação cada vez mais ampliada do fazer artístico com as ciências humanas, assim como um desenvolvimento de sua dimensão política e reflexiva.

Se as relações entre a arte e a filosofia são reconhecidamente intrínsecas desde a experiência clássica antiga, no seio do mundo contemporâneo a arte conceitual trouxe contribuições inegáveis para a reconfiguração de outros modelos tanto para os artistas quanto para as instituições de guarda e conservação dos objetos. Ao acender a discussão sobre a ontologia da obra de arte e reinventar os locais expositivos - diluídos na experiência cotidiana -, assistiuse o desgaste paralelo da obra de arte como mero produto mercadológico em 
favor da ocupação de um lugar mais reflexivo e socialmente participativo. Para os pioneiros da arte conceitual, a discussão filosófica tornou-se tarefa do próprio artista como parte do processo de trabalho, muitas vezes inacabado e dependente de um diálogo com o espectador. Tais premissas deixaram rastros cuja pertinência se estende até os dias de hoje, quando a produção textual-reflexiva é quase indispensável para as novas gerações e sua incansável reinvenção do fazer artístico.

E o que dizer da relação entre a arte e a literatura? Esta também tem se propagado com grande potencialidade, sobretudo após a incorporação efetiva da imagem mecânica na arte, processo paralelo ao questionamento gradativo, de teóricos da arte e da filosofia, acerca da impossibilidade de representação do real. A fotografia, o cinema, o vídeo e, nos últimos anos, a imagem digital tornaram-se ferramentas artísticas de reforço dos tensionamentos entre o que se acredita ser a realidade e aquilo que as suas diferentes parcerias com o ficcional incitam como produção discursiva de potencial crítico inerente. Assim, os diálogos entre a filosofia, a literatura e a arte se mostram bastante profícuos, principalmente no momento cultural que vivemos, no qual assistimos a imagem se sobrepor aos fatos numa era que confirma a comunicação em redes e seus oscilantes desdobramentos entre o instrutivo e o perverso.

Promover de forma sistemática este encontro de disciplinas afins em uma mesma publicação é o desafio e, ao mesmo tempo, o motor principal da nossa revista. Que seja promissor o horizonte de discussões que se abre com o conjunto de textos instigantes deste primeiro número

\section{Referência para citação deste editorial}

SANTOS, A. Editorial - Discutir pensamentos, palavras e imagens. Revista PHILIA | Filosofia, Literatura \& Arte, Porto Alegre, volume 1, número 1, xi xii, fevereiro de 2019. 